\title{
PERFORMANSI PARTISIPASI PEMBELAJARAN BAHASA DI POLITEKNIK LP3i MEDAN
}

\author{
Tasnim Lubis \\ Politeknik LP3i Medan \\ e-mail: tasnimlubis@yahoo.com
}

\begin{abstract}
Abstrak
Penelitian ini mendiskusikan tentang performansi partisipasi pembelajaran bahasa (PPPB) di Politeknik LP3i Medan. Fokus penelitian adalah menemukan pola performansi partisipasi yang terdapat pada proses pembelajaran bahasa di kelas melalui konsep pendekatan antropolinguistik yang mencakup teks, ko-teks, dan konteks. Pola partisipasi yang ditemukan merupakan data penting yang dapat mendeskripsikan fenomena aktivitas bertutur dalam situasi yang dimaksud. Dengan ditemukannya pola tersebut, maka dapat diketahui bagaimana menerapkan model pengajaran dalam proses belajar mengajar yang efektif. Data penelitian adalah rekaman video, wawancara mendalam dan observasi partisipasi. Metode etnografi yang dikemukakan oleh Spradley (1979, 1980) diaplikasikan dalam penelitian ini dari pengumpulan data hingga menganalisisnya. Teori partisipasi yang digunakan adalah tipe struktur partisipasi yang dikemukakan oleh Philips dan kerangka partisipasi menggunakan pendapat Goffman. Hasil penelitian menunjukkan bahwa performansi partisipasi mahasiswa dalam pembelajaran bahasa adalah performansi partisipasi menguji, mengonfirmasi, dan mencari tahu. Performansi partisipasi menguji terdapat pada struktur partisipasi tipe I yaitu pada saat tugas presentasi, sedangkan performansi mengonfirmasi dan mencari tahu terdapat pada struktur partisipasi tipe IV yaitu pada saat tugas menulis.Temuan lainnya adalah bahwa terdapat pergeseran makna dari teks ujaran yang dikodekan dengan kalimat interogatif menjadi imperatif dikarenakan ujaran sangat berhubungan erat dengan niat (intension).
\end{abstract}

Kata kunci: Partisipasi, performansi, pembelajaran, Politeknik LP3i Medan

\section{A. PENDAhULUAN}

Partisipasi memiliki peran penting dalam berbicara. Melalui informasi yang diperoleh dari suatu performansi partisipasi dapat menunjukkan pola berbicara komunitas penuturnya. Penelitian ini menggunakan pendekatan antropolinguistik yang dikemukakan oleh Sibarani. Sibarani (2014: 272-273) menyatakan bahwa kajian tradisi lisan menjelaskan makna dan pola tradisi lisan yang diteliti secara holistik. Makna dapat dipahami sebagai fungsi, nilai, norma, dan kearifan lokal, sedangkan "pola" dapat dipahami sebagai kaidah, struktur, dan formula.

Penelitian tradisi lisan dapat dilakukan dengan menggunakan pendekatan antropolinguistik tradisi lisan mengandung teks, elemen-elemen linguistik, dan budaya. Sibarani (2014) menjelaskan bahwa analisis bentuk struktur sebuah tradisi lisan tidak dapat dipisahkan dari teks, ko-teks dan konteksnya. Teks, ko-teks dan konteksnya dapat diperoleh dari analisis performansi karena seluruh komponen (teks, ko-teks dan 
konteks) hadir secara bersamaan dalam performansi. Performansi partisipasi dapat menginformasikan kondisi pembelajaran dalam kelas dan pola partisipasi yang dilakukan mahasiswa. Penelitian performansi partisipasi merupakan penelitian yang penting karena mendeskripsikan tampilan dari suatu produksi ujaran yang dapat dilihat dan diamati. Tampilan tersebut merupakan kebiasaan yang berlaku dan menjadi bentuk baku yang merupakan data untuk melakukan evaluasi dan mengetahui tindakan yang akan diambil selanjutnya. Contohnya dalam pengajaran bahasa baik bahasa Indonesia maupun bahasa asing, banyak peneliti yang telah menerapkan metode, teknik, maupun model pembelajaran, akan tetapi tidak memerhatikan dan mempertimbangkan suasana partisipasi yang terjadi antara pengajar dan mahasiswa. Padahal, aktivitas partisipasi merupakan hal yang penting diketahui karena termasuk dalam langkah awal sebelum penerapan metode/teknik pengajaran dan evaluasi untuk pengajaran kedepannya.

Performansi dalam proses pembelajaran bermula dari partisipasi yang terjadi dalam proses tersebut. Bagaimana situasi peralihan berbicara yang terjadi antara dosen dengan mahasiswa dan antara mahasiswa dengan mahasiswa selama proses pembelajaraan di dalam kelas berlangsung. Penerapan pembelajaran yang berpusat pada mahasiswa (students centered) mungkin berhasil dibeberapa tempat akan tetapi belum tentu ditempat yang lain. Ada beberapa hal yang harus diperhatikan sebelum menerapkan student centered karena sangat berkaitan dengan perilaku yang dimiliki. Di Negara budaya barat yang memperbolehkan mahasiswa menyela, menginterupsi atau bertanya pada saat dosen sedang mengajar tentu tidak akan menimbulkan masalah pada saat hal tersebut terjadi. Akan tetapi berbeda dengan budaya Indonesia, menginterupsi atau menyela dosen yang sedang bicara pada saat mengajar merupakan tindakan yang berlawanan dengan etika dan norma yang dianut karena menyela orang yang lebih tua pada saat berbicara dianggap kurang sopan. Artinya, ada karakter dan kondisi yang harus dimiliki sebelum menerapkan sebuah metode/teknik. Ini merupakan hal yang perlu diperhatikan agar penerapan metode/teknik pembelajaran dapat berjalan dengan baik pada saat ingin menerapkan kondisi student centered.

Untuk itu, penelitian performansi partisipasi pada pembelajaran dilakukan dengan tujuan untuk mendeskripsikan pola/bentuk partisipasi yang dilakukan mahasiswa dalam proses pembelajaran di pertemuan kelas. Partisipasi dalam konsep penelitian ini adalah kegiatan alih wicara (shifting or turn taking) yang terjadi dalam 
proses pembelajaran di pertemuan kelas (formal). Duranti (1997: 280) menyatakan bahwa partisipasi adalah dimensi dari berbicara yang memiliki akar gramatikal secara baik yang ditunjukkan melalui kerja pada deiksis dan metalinguistik atau bingkai metapragmatik. Untuk memeroleh bentuk yang merupakan pola partisipasi dan isi yang terdapat di dalamnya. Pendekatan antropolinguistik digunakan karena ujaran sangat berkaitan dengan perilaku penuturnya. Dalam antropolinguistik, untuk mengetahui suatu performansi, komponen-komponen di dalamnya yang mencakup teks, ko-teks, dan konteks dapat memberikan makna performansi yang ditampilkan.

Pendekatan antropolinguistik umumnya digunakan untuk mengkaji tradisi lisan yang berkaitan dengan adat istiadat setempat. Hal ini bertujuan untuk menemukan pola berbicara sebagai bagian dari praktik budaya yang dapat menemukan makna, fungsi, nilai, dan norma dari suatu tradisi lisan serta menemukan model revitalisasinya. Akan tetapi, pendekatan antropolinguistik juga dapat digunakan untuk meneliti performansi pada proses pembelajaran, perkantoran dan sebagainya hanya saja tidak meneliti nilai, norma dan model revitalisasi karena bukan merupakan budaya warisan akan tetapi penjelasan fenomena. Penelitian ini menggunakan performansi partisipasi pada pembelajaran bahasa.

\section{B. KAJIAN TEORI}

\section{Partisipasi}

Duranti (1997: 280) menyatakan bahwa partisipasi dalam sosiolinguistik cenderung meneliti tentang fokus kepada partisipasi terhadap sebuah isu antara seorang individu dan kelompok besar yang diteliti yang memiliki homonim dengan hubungan sosial/jaringan sosial. Sedangkan para ahli antropologi linguistik cenderung mempelajari tentang bahasa yang digunakan dalam interaksi tatap muka seperti alih wicara dalam upacara, performansi oratori, aktivitas-aktivitas naratif, canda, dan argumen. Perbedaan lainnya adalah yang pertama bekerja di komunitas perkotaan (besar), sedangkan yang kedua penelitinya bekerja di tempat yang lebih kecil seperti di pedesaan. Akan tetapi saat ini, imu antropolinguistik juga dibutuhkan untuk menemukan pola partisipasi di daerah perkotaan seperti pada situasi pengajaran di sekolah, di rumah sakit, di taman, di warung internet bahkan di jalan raya. 
Pengertian partisipasi berasal dari tiga orang peneliti yang menganalisis partisipasi sebagai titik awal dari penelitian berbicara. Yang pertama adalah Philips dalam Duranti (1997) yang mengemukakan struktur partisipasi, selanjutnya Goffman dan Goodwin dalam Duranti (1997) yang mengemukakan kerangka partisipasi. Struktur partisipasi menurut Philips dipahami sebagai tipe tertentu susunan kerangka dari interaksi. Sedangkan Goffman yang memperluas kajian Hymes mengenai tipe-tipe dari partisipasi memperkenalkan istilah footing (posisi atau penjajaran yang diambil oleh seorang individu dalam mengujarkan sebuah ekspresi linguistik) yang membagi partisipan menjadi principal, author dan animator. Principal adalah orang atau institusi yang memiliki posisi atau yang mewakili. Author adalah orang yang bertanggung jawab untuk pemilihan kata-kata dan sentimen yang dihadirkan. Animator yang juga sering merujuk kepada "sounding box" adalah orang yang memroduksi ujaran yang mengandung pesan yang disampaikan.

Dalam penelitian ini, principal dan author adalah dosen karena dosen merupakan perwakilan dari institusi untuk mengajarkan materi dan bertanggung jawab terhadap hasil pembelajaran. Demikian pula dengan author yang juga adalah dosen dengan karakteristik menguasai kelas dengan menciptakan kondisi pembelajaran. Sedangkan animator adalah dosen dan mahasiswa sebagai penutur atau pemroduksi ujaran. Pembicara mungkin mengisi ketiga peran tersebut, tetapi mereka tidak juga harus melakukannya, dan mungkin tidak melakukannya secara bersamaan (Marks, 2012). Data berupa teks percakapan, wawancara mendalam dan observasi. Teks percakapan diambil dari beberapa pertemuan dalam kelas. Wawancara dilakukan secara terpisah untuk mengetahui makna ujaran yang diproduksi mahasiswa sewaktu pertemuan di dalam kelas. Observasi dilakukan untuk melengkapi data teks dan wawancara.

\section{Performansi}

Konsep performansi dalam penelitian ini bersumber dari tradisi lisan. Beberapa para ahli yang mengemukakan istilah performansi adalah Hymes, Finnegan, dan Bauman. Sedangkan Finnegan (2005: 86) menjelaskan bahwa performansi (budaya lisan) adalah sebagai sebuah moda khusus dari komunikasi dan tindakan manusia yang membedakannya dari (hanya) mendeskripsikan cara normal atau keseharian. Ia juga menambahkan bahwa performansi dapat berada dalam banyak situasi, dari yang 
terorganisasi (tersusun) dan terencana hingga situasi yang tidak formal. Hymes dalam Duranti (1997) menyatakan bahwa performansi adalah sesuatu yang kreatif, berwujud, dan berterima. Selanjutnya, performansi yang dikemukakan oleh Sibarani (2015) bahwa struktur dan formula unsur verbal dan non-verbal tradisi lisan dapat dijelaskan melalui pemahaman struktur teks, ko-teks, dan konteksnya dalam suatu performansi sehingga pemahaman bentuk itu juga menjadi pemahaman keseluruhan. Parameter analisis antropolinguistik adalah keterhubungan (interconnection), kebernilaian (cultural values), keberlanjutan (continuity) Sibarani (2004: 64).

Keterhubungan itu mungkin hubungan linier yang secara vertikal atau hubungan formal yang secara horizontal. Hubungan formal berkenaan dengan struktur bahasa atau teks dengan konteks (situasi, budaya, sosial, ideologi) dan ko-teks (paralinguistik, gerak-isyarat, unsur-unsur material) yang berkenaan dengan bahasa, sedangkan hubungan linier berkenaan dengan struktur alur seperti performansi) menyatakan bahwa tiga parameter yang terdapat dalam antropolinguitik yaitu keterhubungan, kebernilaian dan keberlanjutan.

Untuk penelitian tradisi lisan yang berasal dari budaya etnik, ketiga hal tersebut harus dilakukan untuk mendapatkan model revitalisasinya sebagai kekayaan bangsa. Akan tetapi dalam kasus pembelajaran, keberlanjutan tidak untuk menemukan model revitalisasinya, akan tetapi lebih kepada menemukan model partisipasi yang hadir sehingga dapat menjadi titik tolak untuk menerapkan model, metode, atau strategi dalam mengajar. Teks adalah ujaran yang dihasilkan oleh principal, author, dan animator, sedangkan ko-teks adalah semua unsur yang hadir bersamaan dengan teks yang juga memiliki peran terhadap makna dan fungsi ujaran yang disampaikan. Konteks adalah situasi yang terdapat pada saat peristiwa tutur terjadi. Dalam hal ini, terjadi dalam konteks formal.

\section{Pembelajaran}

Pembelajaran secara hakikat adalah proses pemerolehan pengetahuan. Pemerolehan ini bisa diperoleh dari mengamati, mendengarkan (diajarkan), melakukan atau berdasarkan pengalaman. Menurut Dimyati dan Mudjiono dalam Sagala (2011: 62) pembelajaran adalah kegiatan guru secara terprogram dalam desain instruksional untuk membuat belajar secara aktif, yang menekankan pada penyediaan sumber belajar. 
Dalam Undang-Undang No. 20 Tahun 2003 Tentang Sistem Pendidikan Nasional pasal 1 ayat 20 dinyatakan bahwa Pembelajaran 11 adalah Proses interaksi peserta didik dengan pendidik dan sumber belajar pada suatu lingkungan belajar. Dalam UndangUndang No. 20 Tahun 2003 Tentang Sistem Pendidikan Nasional pasal 1 ayat 20 dinyatakan bahwa Pembelajaran 11 adalah proses interaksi peserta didik dengan pendidik dan sumber belajar pada suatu lingkungan belajar. Konsep pembelajaran menurut Corey (Sagala, 2011: 61) adalah suatu proses dimana lingkungan seseorang secara disengaja dikelola untuk memungkinkan ia turut serta dalam tingkah laku tertentu dalam kondisi-kondisi khusus atau menghasilkan respons terhadap situasi tertentu, pembelajaran merupakan subset khusus dari pendidikan.

Pembelajaran mengandung arti setiap kegiatan yang belajar adalah serangkaian kegiatan jiwa raga untuk memperoleh suatu perubahan tingkah laku sebagai hasil dari pengalaman individu dalam interaksi dengan lingkungannya yang menyangkut kognitif, afektif dan psikomotor (Mayer, 2008: 7). Terdapat dua jenis pembelajaran yaitu secara formal dan informal. Pembelajaran yang difokuskan dalam penelitian ini adalah pembelajaran dalam situasi formal. Dikarenakan berada dalam situasi formal, terdapat standarisasi yang akhirnya berujung kepada penilaian. Pembelajaran dalam hal ini menghadirkan pengajar (dosen) dan mahasiswa. Mahasiswa yang belajar di Politeknik LP3i Medan semuanya berasal dari Indonesia, yang terdiri dari berbagai suku seperti Melayu, Batak, Mandailing, dan Jawa. Diagram kerangka penelitian performansi partisipasi dalam kelas dengan menggunakan pendekatan antropolinguistik dapat dilihat pada gambar 1 sebagai berikut:

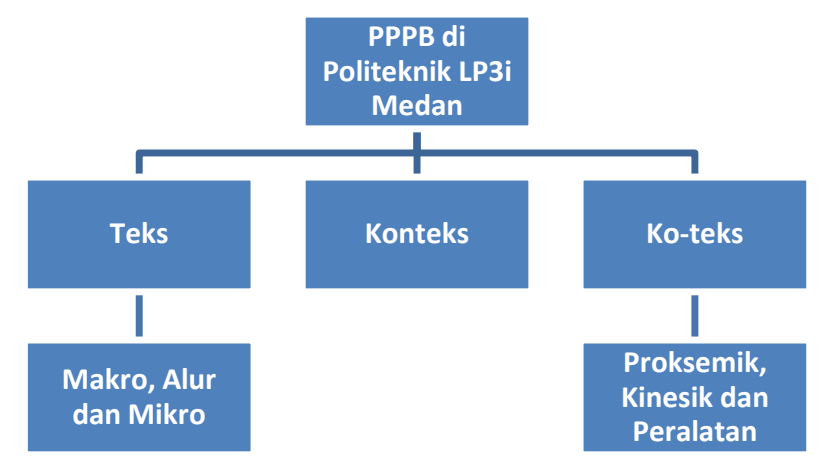

Gambar 1 Diagram kerangka penelitian performansi partisipasi dalam kelas dengan menggunakan pendekatan antropolinguistik 


\section{METODE PENELITIAN}

Penelitian ini dilakukan di Politeknik LP3i Medan. Partisipannya adalah dosen dan mahasiswa Administrasi Bisnis (AB) 18.03 dan AB 18.04 pada pembelajaran Bahasa Indonesia di semester ganjil 2018/2019. Jumlah mahasiswa di kelas AB 18.03 adalah 23 orang dan jumlah mahasiswa di kelas AB 18.04 adalah 20 orang. Penelitian ini menggunakan metode etnografi yang dikemukakan oleh Spradley $(1979,1980)$ yang terdiri dari 12 langkah wawancara dan 12 langkah observasi. Teknik pengumpulan data dilakukan melalui wawancara mendalam dan observasi partisipasi. Spradley (1979: 58) menjelaskan bahwa pemikiran yang terbaik mengenai interview etnografi yaitu serangkaian percakapan yang ramah yang dilakukan oleh peneliti ketika memperkenalkan elemen-elemen baru untuk membantu informan merespon sebagai informan. Selanjutnya, untuk partisipan observasi partisipasi, Spradley (1980: 54) menyatakan bahwa partisipan adalah mengamati sebuah situasi sosial dengan dua tujuan: (1) untuk terikat dalam aktivitas tertentu di situasi tersebut dan (2) untuk mengamati aktivitas, orang, dan aspek-aspek sosial dari situasi tersebut. Untuk mengetahui performansi yang ditampilkan, maka data di analisis dengan menggunakan analisis domain untuk mengetahui keterhubungan, analisis taksonomi untuk mengetahui klasifikasi, dan analisis komponen untuk mendapatkan karakter partisipasi yang diperformansikan. Penggunaan metode etnografi pada penelitian ini dapat dilihat pada gambar 2 berikut:

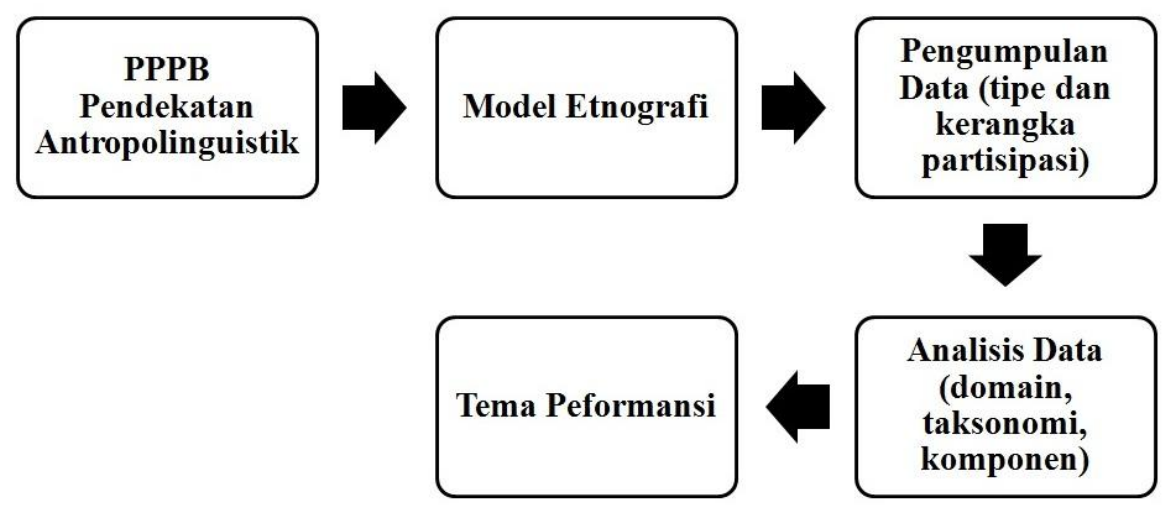

Gambar 2 Diagram penggunaan metode etnografi pada penelitian PPPB di Politeknik LP3i Medan 


\section{HASIL DAN PEMBAHASAN}

Tujuan dari pengajaran bahasa Indonesia di Politeknik LP3i Medan agar mahasiswa mampu berbicara dan menulis dengan baik serta benar pada situasi formal. Artinya, pembelajaran bahasa merupakan proses pembelajaran untuk mendapatkan pengetahuan dan kemampuan dalam menggunakan bahasa sesuai dengan situasi yang dihadapi dengan menggunakan bahasa yang standar dalam situasi formal. Seperti diketahui bahwa bahasa Indonesia memang merupakan bahasa yang dipergunakan sehari-hari, akan tetapi mahasiswa diwajibkan untuk menguasai penggunaan bahasa dalam situasi formal seperti dalam melakukan presentasi, atau pada saat berbicara dan menulis dalam situasi formal.

Melalui 14 kali pertemuan, dua pertemuan dilakukan dengan memberikan informasi mengenai hal-hal yang dimulai dengan pengenalan, tujuan pembelajaran yang ingin dicapai pada semester tersebut dan struktur presentasi. Pada dua pertemuan ini, tipe struktur yang dilakukan adalah dosen berbicara secara dominan untuk menjelaskan. Penjelasan mengenai tipe struktur partisipasi dan performer dijelaskan berdasarkan tiga analisis yang mencakup analisis domain, analisis taksonomi, dan analisis komponen untuk mendapatkan karakter partisipasi yang diperformansikan.

\section{Analisis domain.}

Dalam penelitian ini, domainnya adalah performansi dengan partisipasi sebagai jenis dari performansi dan performer partisipasi sebagai bagian dari performansi. diagram analsis domain dapat dilihat pada gambar 3 sebagai berikut:

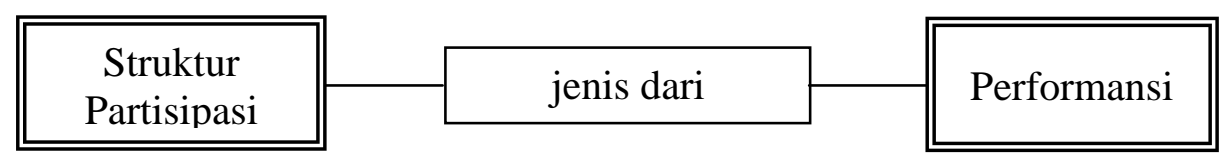

Gambar 3 Diagram analisis domain dengan hubungan semantik jenis pada penelitian PPPB di Politeknik LP3i Medan

Dalam gambar 3, struktur partisipasi merupakan fokus tipe dengan hubungan semantik jenis yang menghubungkannya dengan performansi yang ditampilkan di dalam kelas. Struktur partisipasi selanjutnya diklasifikasikan ke dalam tipe-tipe struktur yang terdapat di dalam pembelajaran bahasa di dalam kelas. 


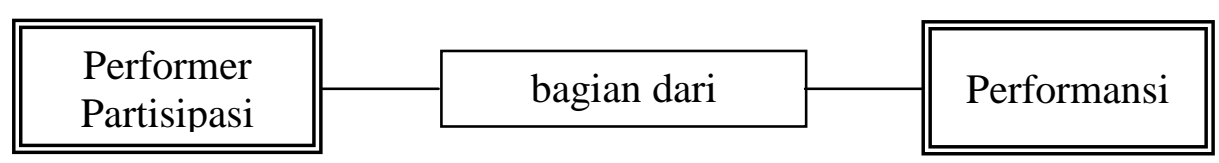

Gambar 4 Diagram analisis domain dengan hubungan semantik bagian pada penelitian PPPB di Politeknik LP3i Medan

Dalam gambar 4, performer partisipasi juga merupakan fokus partisipasi manusia sebagai pemroduksi ujaran. Untuk menghubungkannya dengan domain performansi, maka hubungan semantik jenis menjembatani yaitu menunjukkan bahwa performer merupakan bagian dari performansi yang ditampilkan di dalam kelas.

\section{Analisis Taksonomi}

Selanjutnya adalah mengklasifikasikan struktur partisipasi dan performer partisipasi sesuai dengan tipe yang terjadi di dalam kelas. Kemudian, kerangka partisipasi atau performer juga terbagi ke dalam principal, author dan animator. Philips dalam Duranti (1997) menyatakan berdasarkan penelitiannya, bahwa ada empat tipe struktur partisipasi mendasar yaitu (1) tipe I yaitu melibatkan interaksi keseluruhan kelas dengan pengajarnya. Tipe ini fokus kepada seorang siswa yang ditunjuk untuk melakukan tugasnya seperti show and tell. Dalam tipe ini, semua mahasiswa mendapatkan giliran untuk berbicara, (2) tipe II yaitu melibatkan kelompok kecil siswa dimana sisanya menyelesaikan tugasnya, (3) tipe III yaitu melibatkan interaksi masingmasing mahsiswa dengan pengajarnya, dan (4) tipe IV berbeda dari ketiga tipe sebelumnya yaitu menyuruh siswa untuk mengerjakan tugasnya masing-masing dengan menuliskannya di kertas kerja.

Pada pemelajaran bahasa, tipe yang terdiri dari dua yaitu tipe yang melibatkan kelompok kecil mahasiswa yang berjumlah 3-4 orang untuk tugas presentasi dan tipe mengerjakan tugasnya masing-masing untuk tugas menulisnya. Meskipun demikian, kedua tugas tersebut tetap melibatkan diskusi. Contohnya, pada tugas presentasi, setelah mahasiswa mempresentasikan topiknya, selanjutnya dilakukan proses tanya jawab dan di bagian akhir, mahasiswa diperbolehkan bertanya dengan dosennya jika masih ada 
hal-hal yang kurang jelas atau perluasan mengenai topik yang dipelajari pada hari itu. Diagram dari klasifikasi tersebut dapat dilihat pada gambar 5 sebagai berikut:

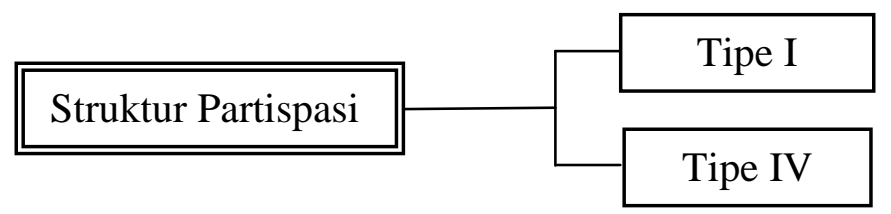

Gambar 5 Diagram klasifikasi struktur partisipasi

Sesuai dengan tipe yang dikemukakan oleh Philips, tipe struktur partisipasi yang digunakan adalah tipe I dan tipe IV. Secara praktis, tipe struktur partisipasi I ini memberikan kesempatan bagi mahasiswa untuk praktik berbicara dalam suasana formal serta secara langsung dapat mengetahui hambatan serta kesulitan yang dihadapi pada saat berbicara di depan umum. Untuk tugas menulis, digunakan tipe IV yang memiliki sedikit perbedaan dengan yang dikemukakan oleh Phillips karena pada tipe ini mahasiswa masih melakukan interaksi baik kepada dosen atau sesama mahasiswa.

Pada situasi ini, sebelum mahasiswa mengerjakan tugas menulis mereka, mereka mengunjungi perpustakaan dan memilih sebuah Tugas Akhir (TA) yang sesuai dengan program studi mereka. Selanjutnya, mahasiswa menjawab pertanyaan yang diberikan dalam bentuk tertulis dan mereka menyelesaikan tugas tersebut berdasarkan TA yang telah mereka pilih. Dalam tipe keempat ini, mereka mengerjakan tugasnya masingmasing karena memiliki TA yang berbeda. Akan tetapi interaksi tetap terjadi baik antara mahasiswa dan dosen dan antara sesama mahasiswa jika mereka mendapatkan kesulitan seperti kurang memahami pertanyaan atau sekedar meyakinkan bahwa apa yang mereka pahami sama seperti temannya. Situasi yang sama juga terjadi pada saat tugas menulis diberikan. Untuk klasifikasi performer, pembagian berdasarkan kerangka partisispasi yang dkemukakan oleh Goffman, dapat dilihat pada diagram berikut:

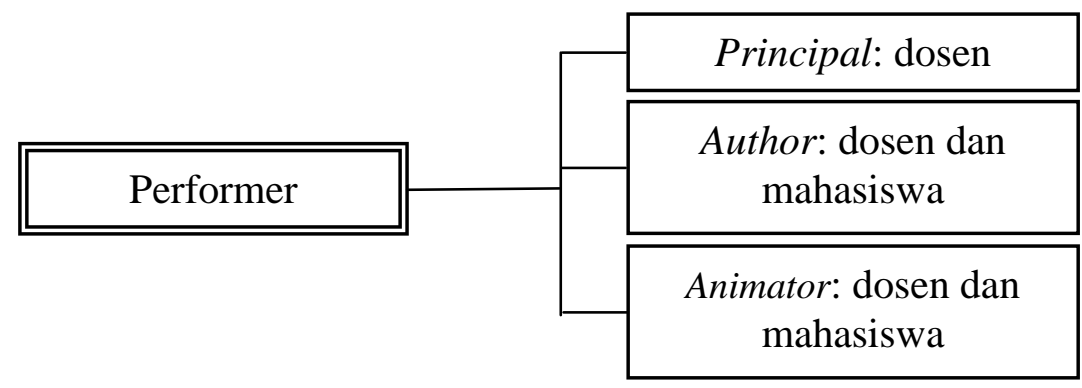

Gambar 6 Diagram klasifikasi performer partisipasi 
Performer berdasarkan kerangka partisipasi yang dikemukakan oleh Goffman, posisi principal diperankan oleh dosen sebagai pihak yang bertanggung jawab atas pesan yang disampaikan. Untuk posisi author dilakukan oleh dosen dan mahasiswa, akan tetapi dalam proses ini, dosen lebih dominan mengendalikan kondisi (framing). Bateson (1972) memperkenalkan istilah "frames" sebagai sebuah bagian dari wacana yang menandai bahwa dalam hal seorang pendengar dan pembicara yang saling memahami ujarannya, dan keduanya haruslah sadar dengan konteks yang dimaksud.

Ketika pembicara dan pendengar berada dalam sebuah percakapan dan tidak membagikan sebuah kerangka yang berhubungan, kesalahpahaman dan salah tafsir sering sekali muncul. Mengikuti Bateson, yang lainnya menganalisis bagaimana framing hadir dalam wacana dari akar perspektif dalam antropologi linguistik (Gumperz, 1982) and sociology (Goffman, 1981). Selanjutnya, untuk animator, adalah dosen dan mahasiswa. Sedangkan pihak yang bertanggung jawab terhadap proses pembelajaran, dosen memiliki tujuan dalam mengajar, sehingga bertanggung jawab penuh terhadap hasil pembelajaran dan kondisi yang dihasilkan. Contoh percakapan pada saat memulai proses pembelajaran dapat dilihat sebagai berikut:

Dosen: Assalamualaikum warahmatullahi wabarakatuh. Selamat pagi semua.

Mahasiswa: Waalaikumsalam warahmatullahi wabarakatuh. selamat pagi Ms (laptop sudah tersambiung ke in-focus)

Dosen: Ok, hari ini kelompok lima dengan topik Paragraf yang akan mempresentasikan tugasnya, kelihatannya sudah siap, jadi kelompok lima silahkan maju

(kelompok yang bertugas maju ke depan dan mengatur posisi. Selanjutnya proses presentasi berangsung)

Pada saat sedang presentasi, terkadang ada mahasiswa yang gugup dan gemetar sehingga terlihat jelas dari performansinya. Jika terdapat kesalahan dalam menyebutkan kosakata, hampir semua mahasiswa menertawakan. Untuk mengatasi hal tersebut, dosen langsung mengambil alih bicara untuk menenangkan kondisi belajar dan memotivasi untuk selalu menghargai proses belajar. Ujaran yang disampaikan adalah sebagai berikut:

Dosen: Ok...ok, perhatian sebentar. Ms hanya ingin menyampaikan bahwa memang tidak mudah berada di depan dan kemungkinan bisa saja melakukan kesalahan. Ini adalah proses. Tapi, coba sampaikan kepada Ms, siapa yang tidak pernah gugup, tidak pernah gemetar, tidak pernah lupa atau... tidak pernah salah sebut pada saat melakukan presentasi? 
Mahasiswa: (semua diam)

Dosen: $\quad$ Ini adalah proses, salah, perbaiki, salah lagi, perbaiki lagi, kurang pas dan sebagainya memang terjadi. Kita harus saling mendukung supaya kita semua bisa berbicara dengan baik. Hari ini giliran teman kita yang presentasi, besok-besok kita. Bagaimana? Bisa kita belajar dan menghargai teman?

Mahasiswa: (beberapa mengangguk dan mulai serius kembali)

Dari situasi tersebut, dapat dijelaskan bahwa dosen merupakan principal yang bertanggungjawab terhadap kondisi kenyamanan belajar. Untuk itu, sebagai principal, dosen harus bertanggung jawab penuh dalam hal mengendalikan situasi pada saat pembelajaran berlangsung seperti menanamkan sikap saling menghargai dengan saling mendengarkan, memahami jika terdapat kesalahan serta saling memperbaiki. Sikap ini sangat penting dimiliki untuk melawan sikap merendahkandan saling mengejek satu sama lain yang merupakan sikap negatif dalam proses belajar.

Lubis (2015) menjelaskan bahwa mahasiswa dengan sikap negatif seperti kurang percaya diri untuk berbicara dalam bahasa Inggris, takut salah dalam berbicara, dan takut jika diejek oleh teman-temannya, akan sulit dalam belajar bahasa Inggris karena mereka tidak mau mempraktikkannya sama sekali. Selanjutnya pada sesi tanya jawab mahasiswa dengan posisi audiensi diperbolehkan bertanya dengan mengacungkan tangan sebelumnya. Para pemakalah akan memilih tiga orang penanya pada sesi pertama dan tiga orang lagi pada sesi kedua. Ilustrasi yang hadir adalah sebagai berikut:

Penanya: saya ingin bertanya...

Dosen: (menyela) ingat, perkenalkan diri dan dari kelompok berapa

Penanya: Oh iya Ms. Maaf, lupa. Saya Shawma dari kelompok I ingin bertanya mengenai paragraf induktif...

Dalam proses tersebut dosen tetap mengawal kondisi dengan harapan mahasiswa mengikuti struktur presentasi yang telah ditetapkan sesuai dengan waktu yang ditentukan. Melalui wawancara mendalam, mahasiswa memiliki indeksikalitas bahwa jika dalam suatu presentasi adalah perdebatan atau saling mengalahkan pemakalah dengan memberikan pertanyaan yang sulit sehingga jika tidak bisa dijawab akan dianggap hebat. Dalam mengatasi hal tersebut, dosen kembali megingatkan mengenai tujuan melakukan presentasi dan pencapaiannya.

Berdasarkan hasil pengamatan dan wawancara mendalam, mahasiswa diposisi penanya berkali-kali melakukan pola yang serupa seperti lupa menyebutkan nama dan 
asal kelompoknya, menginterupsi ketika pemakalah sedang menjawab/menjelaskan, dan sebagian kecil menanyakan pertanyaan yang jauh relevansinya dengan topik. Pada posisi pemakalah, permasalahan yang terjadi adalah rasa gugup dan kurang percaya diri, kurang memahami materi dan kurang berlatih, serta mengendalikan emosi pada saat menyikapi sikap penanya. Hal ini berarti sangat membutuhkan pemahaman dengan penjelasan berulang mengenai giliran berbicara (turn taking), kekonsistenan memulai dan menutup percakapan (bagi penanya dan pemakalah), peralihan giliran presentasi serta yang tercakup ke dalam prosedur presentasi yang telah disampaikan pada dua pertemuan berikutnya.

\section{Analisis komponen}

Pada analisis komponen, karakter tipe I dapat dilihat pada tabel 1 di bawah ini:

Tabel 1 Analisis Komponen Performer dengan Fungsi Ujarannya

\begin{tabular}{|l|l|}
\hline \multicolumn{1}{|c|}{ Performer } & \multicolumn{1}{|c|}{ Fungsi ujaran } \\
\hline Principal (dosen) & Imperatif dan deklaratif \\
\hline Author (dosen dan mahasiswa) & Imperatif, deklaratif, dan interogatif \\
\hline Animator (dosen dan mahasiswa) & $\begin{array}{l}\text { Imperatif, deklaratif, interogatif, dan } \\
\text { penawaran (offer) }\end{array}$ \\
\hline
\end{tabular}

Untuk performansi principal, ujaran-ujaran yang diproduksi oleh dosen memiliki fungsi imperatif dan deklaratif. Contohnya dapat dilihat pada tabel di bawah ini:

Tabel 2 Fungsi Ujaran dan Teks oleh Principal

\begin{tabular}{|l|l|}
\hline Fungsi ujaran & \multicolumn{1}{|c|}{ Teks } \\
\hline Imperatif & $\begin{array}{l}\text { Ok, hari ini kelompok lima dengan topik Paragraf yang akan } \\
\text { mempresentasikan tugasnya, kelihatannya sudah siap, jadi } \\
\text { kelompok lima silahkan maju }\end{array}$ \\
\hline Deklaratif & $\begin{array}{l}\text { Bagus sekali penjelasan dari Taufik mengenai definisi } \\
\text { paragraf. Seperti itulah harusnya ya. Sampaikan definisi } \\
\text { istilah berdasarkan pendapat para ahli dan dilengkapi dengan } \\
\text { nama dan tahunnya. }\end{array}$ \\
\hline
\end{tabular}

Ujaran-ujaran yang disampaikan berdasarkan teks, ko-teks dan konteksnya adalah ujaran memerintah yang dikodekan ke dalam kalimat imperatif. Selanjutnya performansi ujaran sebagai author dan animator yang diproduksi oleh dosen dan mahasiswa dapat dilihat pada tabel berikut: 
Tabel 3 Fungsi Ujaran dan Teks oleh Author dan Animator

\begin{tabular}{|l|l|}
\hline Fungsi ujaran & \multicolumn{1}{|c|}{ Teks } \\
\hline Dosen & \begin{tabular}{l} 
Ok...ok, perhatian sebentar. Ms hanya ingin menyampaikan \\
bahwa memang tidak mudah berada di depan dan kemungkinan \\
bisa saja melakukan kesalahan. Ini adalah proses. Tapi, coba \\
sampaikan kepada Ms, siapa yang tidak pernah gugup, tidak \\
pernah gemetar, tidak pernah lupa atau.. tidak pernah salah \\
sebut pada saat melakukan presentasi?(imperatif) \\
Tantri, Siapa yang tidak hadir hari ini? (interogatif) \\
Pemilihan diksi dalam berbicara sangat penting. Ms beri contoh \\
misalnya kata uang dan duit. Secara definisi tentu saja memiliki \\
makna yang sama yaitu alat yang digunakan untuk melakukan \\
pembayaran, akan tetapi ketika dimasukkan ke dalam kalimat \\
Seperti apa mata uang New Zealand, ms tidak bisa \\
menggantinya dengan mata duit, iya kan? (deklaratif) \\
\hline Nama saya Nael dari kelompok lima. Saya ingin anda \\
memberikan contoh paragraf deduktif (imperatif) \\
Kosakata pasif adalah kosakata yang sudah jarang dipakai \\
seperti kata perigi, tuanku dan sebagainya (deklaratif) \\
Ms, mengapa bahasa kita banyak sekali menggunakan kata-kata \\
dari bahasa lain? (interogatif) \\
Apakah anda sudah puas dengan jawaban kami? (imperatif)
\end{tabular} \\
\hline
\end{tabular}

Dari keempat contoh teks di atas, berfokus kepada mahasiswa, ujaran-ujaran yang disampaikan dikodekan ke dalam kalimat imperatif, interogatif, dan deklaratif. Kalimat imperatif dapat disampaikan dalam bentuk perintah, permintaan, atau ajakan. Akan tetapi bisa terjadi situasi dimana kalimat yang dikodekan ke dalam bentuk interogatif akan tetapi berdasarkan teks, ko-teks, dan konteksnya, merupakan kalimat imperatif. Jika hanya dikaji secara teks saja, maka tidak dapat ditemukan makna yang sebenarnya. Sesuai pendapat Seyfeddinipur dan Gullberg (2014) yang menyatakan bahwa penggunaan bahasa secaramendasar adalah multimodal. Multimodal melibatkan gerakan tubuh, ekspresi wajah, dan tatapan dan juga gesture. Untuk itu melalui data teks yang dikonfirmasi dengan wawancara dan observasi, maka dapat ditemukan bahwa ujaran-ujaran yang disampaikan tidak selalu sesuai maknanya dengan performansi yang ditampilkan.

Melalui komponen teks, ko-teks, dan konteks, ujaran-ujaran yang diproduksi memiliki perbedaan antara pengkodean kalimatnya dengan makna yang diberikan. Contohnya, ujaran-ujaran tersebut dikodekan ke dalam kalimat interogatif, akan tetapi 
tujuannya (intensi) adalah kalimat perintah. Contohnya pada situasi ketika mahasiswa bertanya dengan kelompok pemakalah di depan. Dari hasil wawancara dan observasi ditemukan bahwa mahasiswa bertanya dengan kelompok pemakalah adalah cenderung kepada menguji temannya bahkan merasa puas jika teman pemakalah tidak bisa menjawab pertanyaannya. Contoh ujaran tersebut dapat dilihat sebagai berikut:

(1) "Coba anda sebutkan jenis-jenis diksi”

(2) "Coba anda jelaskan sejarah lahirnya bahasa Indonesia"

Berdasarkan hasil wawancara dan observasi, pertanyaan-pertanyaan tersebut diajukan karena penanya ingin agar pemakalah kewalahan dalam menjelaskan. Padahal penanya sendiri tidak begitu memperdulikan jawaban yang disampaikan karena intensinya adalah cenderung kepada melihat performansi presenter dalam menjawab pertanyaan. Berdasarkan situasi tersebut, terdapat pergeseran, dimana seharusnya yang terjadi adalah saling menyampaikan informasi atau diskusi sehingga terjadi penambahan ilmu pengetahuan mengenai topik pada pertemuan tersebut.

Para pemakalah juga menyampaikan hal serupa yaitu sangat takut dan khawatir jika tidak bisa menjawab pertanyaan dari penanya. Hal ini terepresentasi dari ujaran yang diajukan pemakalah setelah selesai memberikan jawaban kepada penanya. Contoh kalimatnya dapat dilihat sebagai berikut:

(3) "Apakah anda sudah puas dengan jawaban kami?"

(4) "Bagaimana Ari? Apakah sudah puas?"

Meskipun dikodekan ke dalam kalimat interogatif, akan tetapi makna dari kalimat tersebut bukan meminta informasi dari penanya mengenai jawaban yang diberikan pemakalah. Dengan intonasi dan kinesik yang ditunjukkan pada saat menuturkan kalimat tersebut memiliki makna bahwa pertanyaan sudah di jawab oleh pemakalah dan jangan memperpanjangnya untuk menjaga muka pemakalah.

Berdasarkan fenomena di atas, dapat terlihat bahwa terdapat pergeseran performer dimana seharusnya penanya bukan sebagai penguji atau pemakalah bukan berpartisipasi dalam komunikasi searah saja. Di samping pergeseran performer, maka terdapat pula makna teks yang menyimpang dari kalimat interogatif menjadi kalimat imperatif. Makna dari contoh (3) dan (4) jika dikodekan menjadi kalimat imperatif adalah "Sudah kami jawab pertanyaannya, jadi jangan memperpanjangnya lagi ya". Contoh kalimat interogatif lainnya seperti pada saat menanyakan definisi istilah. Ketika 
pemakalah menjelaskan materinya dan menyebutkan istilah asing baik dalam bahasa asing maupun bahasa daerah, mahasiswa penanya akan menanyakan istilah tersebut pada saat sesi tanya jawab dengan tujuan agar para pemakalah kewalahan dalam menjawabnya. Sehingga kalimat yang diujarkan hanya dibungkus secara interogatif akan tetapi berdasarkan ko-teksnya, maknanya adalah kalimat imperatif.

Suasana seperti ini mendominasi pada saat sesi tanya jawab sehingga perlu diberikan pemahaman mengenai perilaku belajar pada saat presentasi. Hal ini disebabkan oleh pengetahuan mahasiswa mengenai presentasi. Dalam perspektif mereka, presentasi adalah kegiatan melakukan debat pendapat seperti yang mereka lihat dan ketahui sebelumnya. Mendengar kata presentasi, maka pikiran mereka terindeks kepada debat pendapat dan siapa yang terkuat. Pendapat Oswalt dalam Duranti (1997) yang berkaitan dengan indeksikalitas adalah sebagai berikut:

Dalam antropologi,suatu budaya dipelajari dan dibagikan mengenai karakterisitik pola perilakunya oleh orang-orang dalam suatu kelompok. Budaya yang anda miliki berasal dari saudara-saudara dan anggota komunitas anda, sama halnya seperti berasal dari bermacam-macam materi seperti dari buku-buku dan program-program televisi. Anda tidak terlahir dengan budaya, akan tetapi dengan kemampuan untuk memperolehnya melalui observasi, meniru, dan dengan uji coba.

(Oswalt 1986: 25)

Artinya, dalam benak para mahasiswa telah terpatri bahwa presentasi adalah kegiatan perdebatan dan mengalahkan. Selanjutnya, Lubis (2017) dalam penelitiannya mengenai indeksikalitas dalam perspektif antropolinguistik menyatakan bahwa mengetahui makna, nilai, dan norma dari suatu komunitas (guyub tutur) merupakan informasi yang penting dalam kehidupan berbangsa dan bernegara. Hal ini dikarenakan perbedaan pola pikir, sudut pandang, akan suatu hal (karakter, fenomena, peristiwa) berbeda antara satu tempat dengan lainnya. Sesuai dengan pendapat tersebut, saat ini konsep presentasi yang dipahami mahasiswa mengindeks kepada debat pendapat sehingga pada kondisi yang tercipta adalah saling menguji dan mengalahkan.

Melalui pendekatan antropolinguistik dapat disimpulkan bahwa performansi partisipasi yang diproduksi mahasiswa dalam kelas pembelajaran bahasa adalah performansi menguji, mengonfirmasi, dan belajar (mencari tahu). Performansi menguji terdapat pada situasi ketika mahasiswa mengajukan pertanyaan kepada pemakalah. Performansi mengonfirmasi dan mencari tahu terjadi ketika mahasiswa saling bertanya pada saat tugas menulis. Performansi partisipasi sangat terkait dengan karakter 
pengguna bahasa. Pada proses penyampaian pesan, dapat saja menggunakan bahasa literal maupun metafora. Ujaran-ujaran yang disampaikan oleh mahasiswa pada saat menanyakan pertanyaan kepada pemakalah sewaktu presentasi sangat didominasi dengan mengucapkan kata coba, sebutkan, atau coba sebutkan dan coba jelaskan.

Kata coba merujuk kepada seseorang yang menguji kemampuan yang lainnya. Padahal, dalam pembelajaran, kondisi yang diinginkan adalah menambah pengetahuan penanya dengan meminta penjelasan atau perspektif dari pemakalah. Peneliti menemukan bahwa sikap negatif seperti menguji ataupun mengejek dapat memengaruhi kemampuan mahasiswa dalam belajar. Lubis (2015) menyatakan bahwa membangun sikap positif dalam mempelajari bahasa Inggris merupakan langkah pertama sebelum menerapkan metode yang sesuai dalam pengajaran. Untuk itu, dosen tidak hanya harus mengajar, akan tetapi juga membangun motivasi dan keberanian para mahasiswanya untuk berbicara.

Menyikapi kondisi performansi partisipasi dalam pembelajaran bahasa di Politeknik LP3i Medan, dosen harus menyesuaikan persentase antara tiga hal penting yang dilakukan dalam mengajar yaitu memberikan pemahaman, memotivasi, dan memberikan materi. Mengajar tidak hanya memberikan materi pembelajaran akan tetapi mempertimbangkan hal-hal lainnya yang berkaitan dengan proses penyampaian materi tersebut. Harmer (2010: 23) menyatakan bahwa mengajar bukanlah hal yang mudah, akan tetapi merupakan hal yang penting, dan dapat sangat berharga ketika kita melihat peningkatan dari para mahasiswa/siswa kita dan mengetahui bahwa kita memiliki peran dalam mewujudkannya. Adalah sangat benar bahwa pelajaran dan para mahasiswa/siswa dapat menyulitkan dan membuat stress pada suatu waktu, akan tetapi juga berharga mengingat bahwa dengan melakukan pengajaran terbaik juga dapat amat sangat menyenangkan. Mempertimbangkan hal lainnya di samping mengajar seperti mengetahui karakter mahasiswa dan pola partisipasi mereka, merupakan faktor penunjang keberhasilan dalam mengajar.

\section{E. KESIMPULAN}

Berdasarkan hasil tersebut, dapat disimpulkan bahwa performansi partisipasi yang terdapat dalam kelas pada saat pembelajaran bahasa pada mahasiswa adalah performansi mahasiswa adalah performansi menguji, mengonfirmasi, dan mencari tahu. Performansi partisipasi dosen adalah performansi memotivasi, mengajar, dan 
menasihati. Tipe partisipasi yang terjadi di dalam kelas terdapat dalam dua tipe yaitu tipe I dan tipe IV seperti yang dikemukakan oleh Phillips, akan tetapi pada perbedaan pada tipe ke IV dimana mahasiswa mengerjakan tugasnya masing-masing di mejanya, akan tetapi tetap berinteraksi dengan mahasiswa dan dosen jika menghadapi kesulitan dalam pengerjaan tugasnya. Umumnya mahasiswa lebih dominan bertanya kepada sesama mahasiswa. Jika ada hal yang tidak atau kurang dipahami maka barulah mahasiswa menanyakannya langsung kepada dosen.

Untuk menghadapi situasi tersebut, sikap (performansi partisipasi) yang harus dihindari adalah performansi sikap menguji sesama mahasiswa karena hal tersebut akan menimbulkan tindakan negatif seperti meremehkan dan mempermalukan. Dampak yang dapat timbul dari performansi partisipasi tersebut tersebut adalah rendah diri, tidak percaya diri, dan dendam. Mahasiswa akan malu untuk bertanya karena akan dianggap bodoh sehingga atmosfir belajar dan tujuan belajar sulit dicapai. Untuk mengatasi hal ini, dibutuhkan performansi partisipasi dosen sebagai pengontrol (principal) untuk menginformasikan sikap-sikap belajar yang baik agar proses pembelajaran dapat berjalan dengan baik pula.

\section{DAFTAR PUSTAKA}

Duranti, A. 1997. Linguistic Anthropology. Cambridge: Cambridge University Press.

Harmer, J. 2010. How to Teach English: new edition. China: Pearson Education Limited.

Lubis, T. Students' Language Attitude Toward English. Jurnal Bisnis Administrasi. Volume 04, Nomor 1, 2015, 17-21: http://ejurnal.plm.ac.id/index.php/BISA/article/download/128/110

Lubis, T. Indeksikalitas dalam Perspektif Antropolinguistik. Prosiding Seminar Antarbangsa: Kajian Linguistik dan Kearifan Lokal. 2017, 128-134.

Marks, A. Participation Frameworks and Footing Shift in an Interpreted Academic Meeting. Journal of Interpretation, Volume 22, Issue 1, 2012, 1- 28: https://digitalcommons.unf.edu/cgi/viewcontent.cgi?article=1011\&context=joi

Sagala, S. 2011. Konsep dan Makna Pembelajaran. Bandung: Alfabeta.

Seyfeddinipur, M and Gullberg, M. 2014. From Gesture in Conversation to Visible Action as Utterance. Amsterdam/Philadephia: John Benjamin Publishing Company.

Sibarani, R. 2012. Kearifan Lokal: Hakikat, Peran, dan Metode Tradisi Lisan. Jakarta Selatan: Asosiasi Tradisi Lisan (ATL).

Sibarani, R. 2004. Antropolinguistik: Antropolinguistik, Linguistik Antropologi. Medan: Poda.

Sibarani, R. 2015. Pembentukan Karakter: Langkah-langkah Berbasis Kearifan Lokal. Jakarta Selatan: Asosiasi Tradisi Lisan (ATL).

Spradley, J. 1979. The Ethnographic Interview. USA: Rinehart and Winston.

Spradley. 1980. Participant Observation. USA: Rinehart and Winston. 